\title{
Decentralized Solar Energy Technology Assessment Program: Research Plan
}

\author{
Benson H. Bronfman \\ Martin Schweitzer \\ Sam A. Carnes \\ Elizabeth Peelle \\ Garland Samuels, Jr. \\ Thomas J. Wilbanks
}




\section{DISCLAIMER}

This report was prepared as an account of work sponsored by an agency of the United States Government. Neither the United States Government nor any agency Thereof, nor any of their employees, makes any warranty, express or implied, or assumes any legal liability or responsibility for the accuracy, completeness, or usefulness of any information, apparatus, product, or process disclosed, or represents that its use would not infringe privately owned rights. Reference herein to any specific commercial product, process, or service by trade name, trademark, manufacturer, or otherwise does not necessarily constitute or imply its endorsement, recommendation, or favoring by the United States Government or any agency thereof. The views and opinions of authors expressed herein do not necessarily state or reflect those of the United States Government or any agency thereof. 


\section{DISCLAIMER}

Portions of this document may be illegible in electronic image products. Images are produced from the best available original document. 


\section{Printed in the United States of America. Available from}

National Technical Information Service

\section{U.S. Department of Commerce}

5285 Port Royal Road, Springfield, Virginia 22161

Price: Printed Copy $\$ 4.50$; Microfiche $\$ 3.00$

This report was prepared as an account of work sponsored by an agency of the United States Government. Neither the United States Government nor any agency thereof, nor any of their employees, contractors, subcontractors, or their employees, makes any warranty, express or implied, nor assumes any legal liability or responsibility for any third party's use or the results of such use of any information, apparatus, product or process disclosed in this report, nor represents that its use by such third party would not infringe privately owned rights. 
Contract No. W-7405-eng-26

ENERGY DIVISION

DECENTRALIZED SOLAR ENERGY TECHNOLOGY ASSESSMENT PROGRAM: RESEARCH PLAN*

Benson H. Bronfman Martin Schweitzer Sam A. Carnes Elizabeth Peelle Garland Samuels, Jr. Thomas J. Wilbanks

Date Published - May 1979

* Research sponsored by the Office of Solar, Geothermal, Electric and Storage Systems, Department of Energy, under contract W-7405-eng-26 with the Union Carbide Corporation

OAK RIDGE NATIONAL ILABORATORY Oak Ridge, Tennessee 37830 operated by UNION CARBIDE CORPORATION for the DEPARTMENT OF ENERGY

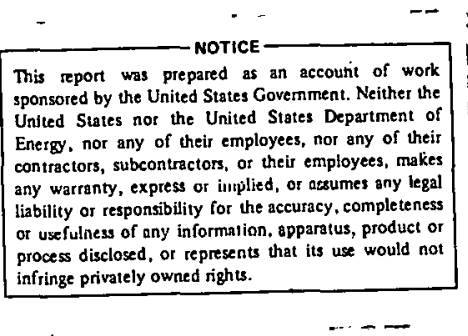

$\cdots-$ 


\section{THIS PAGE}

\section{WAS INTENTIONALLY}

\section{LEFT BLANK}


CONTENTS

$\underline{\text { Page }}$

LIST OF FIGÜRES . . . . . . . . . . . . . . . . . . . . . iv iv

LIST OF TABLES . . . . . . . . . . . . . . . . . . . . . . v v v v

ABSTRACT . . . . . . . . . . . . . . . . . . . . vil

INTRODUCTION . . . . . . . . . . . . . . . . . . . $\mathrm{x}$

1.0 PURPOSE AND OBJECTIVES . . . . . . . . . . . . . . . . . . 1

2.0 BACKGROUND . . . . . . . . . . . . . . . . . . . . . . 3

3.0 RELEVANCE TO DOE . . . . . . . . . . . . . . . . . . . . . 5

4.0 APPROACH AND METHODS . . . . . . . . . . . . . . . . . 6

4.1 Phase I. . . . . . . . . . . . . . . . . . . . 6

4.2 Phase II . . . . . . . . . . . . . . . . . . . . 11

4.3 Background and Support Studies . . . . . . . . . . 15

5.0 COMMUNTT LEVEL TECHNOLOGY ASSESSMENT PLAN: TASK I-1 . . . . . 18

6.0 SOCIAL COST PLAN: TASK I-2 . . . . . . . . . . . . . . . 21

6.1 Activity I-2-A: Social Costs Assessment . . . . . . . . 21

6.2 Activity I-2-B: Legal and Institutional Barriers . . . . . 22

7.0 GENERAL SUPPORT PLAN: TASK I-3 . . . . . . . . . . . . . . 32

7.1 Activity I-3-A: Program Revlew Team . . . . . . . . . . 32

7.2 Activity I-3-B: Selected Case Studies . . . . . . . . 33

8.0 EXPANDED COMMUNTTY TECHNOLOGY ASSESSMENT PLAN: TASK II-1 • . . 36

9.0 COMMUNITY IMPACT ASSESSMENT/MONITORING PLAN: TASK II-2 . . . . 38

10.0 SCENARIO DEVELOPMENT PLAN: TASK III-1 . . . . . . . . . . . 41

11.0 SOCIAL ISSUE ANALYSIS PLAN: TASK III-2 . . . . . . . . . . 44 


\section{LIST OF FIGURES}

Figure

$\underline{\text { Page }}$

4.1-1 Milestone Chart - FY 79 - Phase I . . . . . . . . . . 9 9

4.2-1 Milestone Chart - FY 79 - Phase II . . . . . . . . . . 13 
$\underline{\text { Table }}$

$\underline{\text { Page }}$

4.1-1 Milestones - FY 1979 - Phase I . . . . . . . . . . . 8

4.1-2 Management and Resources - Phase I . . . . . . . . . 10

4.2-1 Milestones - FY 1979 - Phase II . . . . . . . . . . . . 12

4.2-2 Management and Resources - Phase II . . . . . . . . . . . . 14

4.3-1 Management and Resources for Background and Support Studies . . . . . . . . . . . . . . . . . 17

5-1 Internal Milestones - Task I-1 . . . . . . . . . . . . 20

6-1 Internal Milestones - Task I-2 . . . . . . . . . . . 31

7-1 Internal Milestones - Task I-3 . . . . . . . . . . 35

8-1 Internal Milestones - Task II-1 . . . . . . . . . . 37

9-1 Internal Milestones - Task II-2 . . . . . . . . . . . 40 


\section{THIS PAGE}

WAS INTENTIONALLY

LEFT BLANK 
DECENTRALIZED SOLAR ENERGY TECHNOLOGY ASSESSMENT PROGRAM:

\section{RESEARCH PLAN}

Benson $\mathrm{H}$. Bronfman

Martin Schweitzer

Sam A. Carnes

Elizabeth Peelle

Garland Samuels, Jr.

Thomas J. Wilbanks

\section{ABSTRACT}

The Decentralized Solar Energy Technology Assessment Program (TAP) is a program sponsored by the office of Solar, Geothermal, Electric and Storage Systems, Department of Energy (DOE). The major purpose of the program is to assess the social, political, institutional and life-style impacts of the widespread adoption of decentralized solar technology. This document describes the mafor components and presents the research plan for the TAP. Responsibilities, milestones and deliverables for all components are identified where applicable. 
THIS PAGE

WAS INTENTIONALLY

LEFT BLANK 


\section{INTRODUCTION}

This document presents the work plan for research conducted in support of ORNL's Decentralized Solar Energy Technology Assessment Program. It was prepared and published as an ORNL Technical Memorandum (TM) at the request of the DOE Program Manager, Mr. James Quinn, Office of Solar, Geotherma1, Electric and Storage Systems, Division of Planning and Technology Transfer. The purpose of the plan, prepared by the professional staff of the Social Impact Analysis Group of the Energy Division at ORNL, is to serve both as a description of the tasks associated with the program and as a guide for research in FY 1979. 


\subsection{PURPOSE AND OBJECTIVES}

The purpose of the Decentralized Solar Energy Technology Assessment Program (TAP) is to evaluate the social, economic, institutional and life-style impacts upon communities of the widespread use of decentralized solar energy technologies. A community-based technology assessment will be utilized in several settings as the primary mode for analysis.

Objective 1. To assess social, economic, institutional and lifestyle impacts of the widespread use of decentralized solar energy.

An assessment of the social impacts of solar energy is needed to make solar development policy sensitive to unanticipated or unintended social impacts and barriers to the deployment of decentralized solar technologies. The TAP can provide a framework or context for integrating generic and technologyspecific assessments underway in other DOE programs.

Objective 2. To involve communities in planning and evaluating their own solar futures.

The nature of solar technologies and their adaptab1l1ty to local situations and preferences makes site-specific community-based assessment a reasonable and needed approach. Allowing a wide range of citizen interests to be factored into the final assessment of decentralized solar energy, it provides an approach to energy planning and technology development which is responsive to local needs and preferences. The dissemination of the results of the TAP will assist other communities in the planning and assessment of their energy futures, and it will assist DOE in prioritizing its research needs and programs. 
Objective 3. To provide a mechanism for diffusing technical information and planning and assessment methods regarding energy development at the local level.

The TAP will provide DOE with a two-way communication link. First, it will develop a method by which communities can do their own assessments of solar and other energy development, and provide a focus through which communities can obtain information and resources required to conduct the assessment. Second, it will provide DOE with information ahnir rirrene and peroolved conccrng and needs al lie local level, for more effective policy development. 


\subsection{BACKGROUND}

It is widely recognized that the introduction of a new technology may have widespread social impacts which were unanticipated, unintended and, in many cases, undesirable. In some cases, unanticipated social impacts have resulted in increased costs, delays and cessation of the implementation of technologies thought to be crucial to national development and energy selfsufficiency. Traditional technology assessment and social impact assessments have attempted to identify and evaluate possible societal impacts of new technologies, but have failed to provide timely information on significant impacts for several reasons.

(1) They have often ignored social, non-quantifiable or noneconomic factors.

(2) They have concentrated upon direct, structural impacts such as service sector utilization, migration, and fiscal impacts while ignoring indirect impacts such as life-style, institutional and value impacts.

(3) They have been undertaken primarily by technology experts with little recognition given to the values brought by the experts to the evaluation, and have had little or no citizen involvement in the assessment process or the evaluation of the results of the process.

The need for a systematic assessment of the consequences of the development of distributed energy systems, and solar energy in particular, is extremely important. The need exists not only because of the significant potential for social consequences but because the most widely used assessment models and methods were developed primarily with large, centralized activities in mind (e.g., power plants, mines, parks) and may not be transferable to the distributed solar energy case. 
Several aspects of distributed energy systems and decentralized solar energy in particular make it imperative that non-traditional assessment techniques and methods be developed.

(1) Decentralized solar energy technologies may have significantly different environmental, social and equity impacts from traditional, large-scale, centralized energy technologies.

(2) Decentralized solar energy technologies have the potential for generating conflict with existing energy distribution and control ayotoma.

(3) Decentralized solar energy technologies are significantly adaptable to community energy needs and community goals.

(4) Decentralized solar energy technologies may require technology utilization decisions by institutions (e.g., communities) whose decision-making processes in such situations are not well understood. 


\subsection{RELEVANCE TO DOE}

The decentralized solar energy TAP will contribute to DOE's effort in the planning and development of policies or programs regarding distributed or decentralized solar energy systems. The technology assessment results should provide significant information in several areas.

The analysis of the perceived impacts of the widespread use of decentralized solar technologies will assist DOE in assessing the economic, social and institutional barriers and incentives to the acceptance of decentralized.solar technologies. As such, it will assist in providing guidance relative to solar technology $\mathrm{R} \& \mathrm{D}$, and design alternatives.

Additionally, the focus on community-based assessment can provide DOE with a significant new tool for comprehensive energy planning at the local level, and thus a more effective way of evaluating and transferring new technologies to a wide range of institutional settings.

Finally, the TAP will provide DOE with a realistic assessment of the potential role of solar energy at the local level as compared to other energy sources, and prototypical examples of preferred solar options. 


\subsection{APPROACH AND METHODS}

The Decentralized Solar Energy Technology Assessment Program (TAP) is composed of three major components which will be referred to as Phase I, Phase II and Background and Support Tasks. Phase I and Phase II tasks constitute research activities directly administered by ORNL. The Background and Support tasks are efforts funded previously by DOE, and are important components of the TAP.

\subsection{Phase I}

Phase I includes four major tasks:

The first task ( $I-1$ ) is the community-based decentralized solar energy technology assessment. The first activity will be to initiate TA's in each of three rural communfties. It is anticipated that all three communities will have their assessments underway in May 1979. A report comparing the plans of the three communities will be available to DOE by June 1 . This report, which will be available for public review in July, will serve as a basis for an ongoing comparison of the three community TA effort, culminating in a final report, tentatively scheduled for the summer of 1980 . Coordination activities among the communities will be described in monthly and quarterly progress reports. This task is described in more detail in Section 5.0 .

A second task ( $I-2)$ w11l be to conduct research into the social costs of alternative energy technologies and of decentralized solar energy in particular. This research will assist local communities in evaluating possible energy development alternatives and wil1. assist DOE in aosessing the relative social costs of alternative technology development polfries. Two activities are planned for this task. An analysis of the quantifiable and nonquantifiable environmental, health and social costs of alternative energy technologies will be undertaken, and a proposed methodology will be developed. A second activity will be an analysis of major legal and institutional barriers to the deployment of decentralized solar technologies. The second task is described in more detail in Section 6.0 . 
A third task (I-3) will be to provide general support for the TAP. Since the need for additional support or research activity will become more apparent as the program develops, this task is expected to remain flexible. Several activities which fall under this task include familiarization with other relevant studies; establishment of an independent review team; selected case studies of solar experiments in other communities; review of proposals from DOE; liaison with SERI and other DOE programs; and monitoring of past activities of the TAP. A more detailed discussion of these activities is presented in Section 7.0.

A fourth and final task of Phase I $(I-4)$ will be to evaluate the TA program results, to assess the feasibility of the methodology, to review DOE policy relevant to the TA program and to suggest new research activities and needed policy directions. This task will require a significant effort, involving not only TA program actors but other technology and policy experts, many of whom are located at ORNL. The end product is expected to be widely circulated and reviewed by DOE, SERI, local and state officials and other experts in the field. A detailed plan for this task will be completed by June 1, 1979.

Major milestones and deliverables for Phase $I$ are presented in Table 4.1-1 and Fig. 4.1-1. Management and resources allocated for Phase I are presented in Table 4.1-2. 
Table 4.1-1. Milestones - FY 1979 - Phase I

\begin{tabular}{|c|c|}
\hline Date & Deliverable \\
\hline $\begin{array}{l}\text { February 22, } 1979 \\
\text { June } 1,1979\end{array}$ & $\begin{array}{l}\text { First Progress Report } \\
\text { Comparison of Community TA Plans } \\
\text { Task Plan for TA Program } \\
\text { Evaluation (Task T-4) }\end{array}$ \\
\hline June 15,1979 & $\begin{array}{l}\text { Draft Sncial Cnst Paper } \\
\text { Draft Legal Barriers Paper }\end{array}$ \\
\hline June 30,1979 & Second Progress Report \\
\hline September 1, 1979 & $\begin{array}{l}\text { Final Social Cost Paper } \\
\text { Final Legal Barriers Paper }\end{array}$ \\
\hline September 30, 1979 & Annual Report \\
\hline
\end{tabular}




\section{Decentralized Solar Energy TA Program - Milestones FY 79 - Phase I}

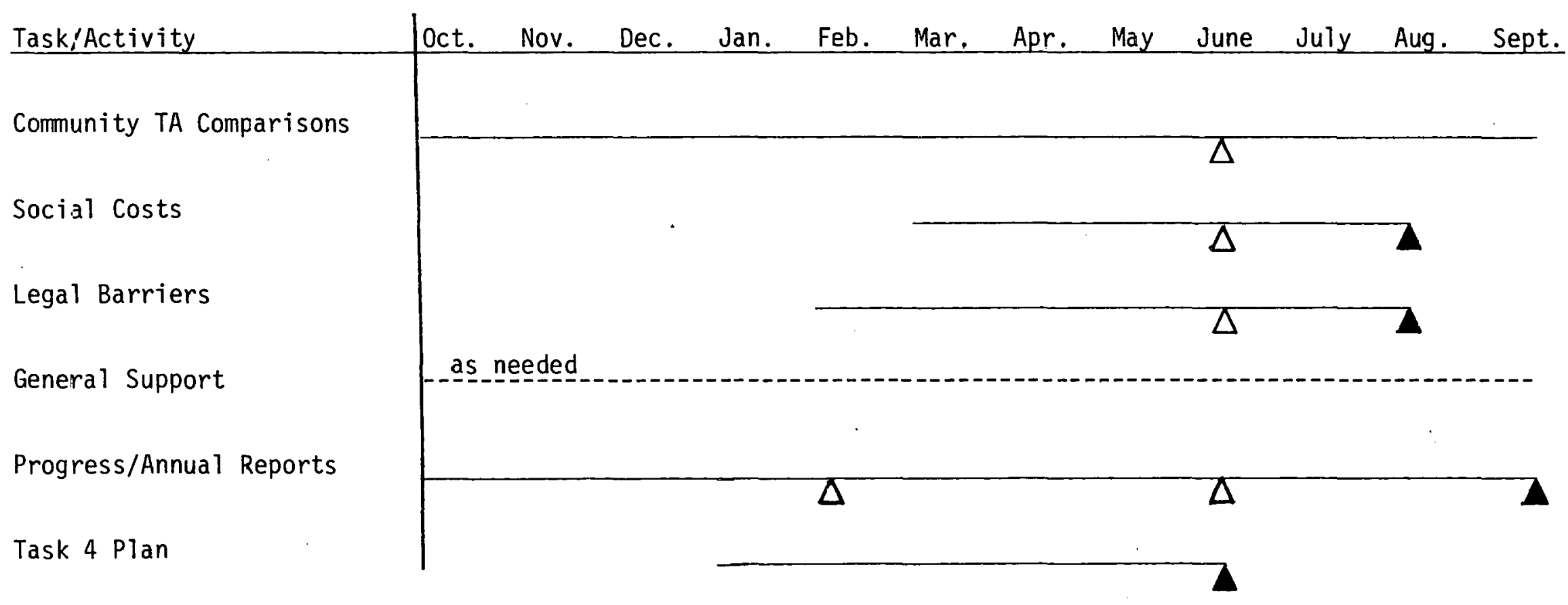

$$
\Delta=\text { draft } \quad \Delta=\text { final }
$$

Fig. 4.1-1. Milestone Chart - FY 79 - Phase I 
Table 4.1-2. Management and Resources - Phase I

MANAGEMENT

Program Manager: Benson H. Bronfman

Task Leaders :

$$
\begin{array}{ll}
\text { I-1 } & \text { M. Schweltzer } \\
& \text { S. A. Carnes } \\
\text { I-\% } & \text { F. Pẹlle } \\
& \text { M. Schwoitber } \\
& \text { G. Samuels } \\
\text { I-3 } & \text { B. H. Bronfman } \\
\text { I-4 } & \text { B. H. Bronfman } \\
& \text { S. A. Carnes } \\
\text { T. J. Wilbanks }
\end{array}
$$

RESOURCES

$$
\begin{array}{ll}
\text { Budget: } & \text { Approximately } 357 \mathrm{k} \\
\text { Staff time: } & 2.0 \text { person/years } \\
\text { Subcontracts: } & 225 \mathrm{k}
\end{array}
$$




\subsection{Phase II}

The Phase II effort is designed to enhance the evaluation and analysis of the results of the program and the validity of the inferences drawn from the community case studies. The Phase II effort is composed of three major tasks.

The first task (II-1) is the addition of two more communities to the TA program to bring the total to five. One community would be Franklin County, Massachusetts, where significant work has already been done on scenario development (see Section 10.0). The other community would be selected from the pool of superior proposals received for the Phase I communities, or would be selected to insure a more equitable geographic distribution of communities. This task is discussed in more detail in Section 8.0 .

The second task (II-2) is the development and implementation of an independent community impact assessment/monitoring effort in each selected community. The purpose of this task is to provide the program manager with an ongoing information gathering source directed at program evaluation and inter-community comparison. A more detailed discussion of this task is presented in Section 9.0.

The final task (II-3) will consist of ongoing and expanded general support to carry the program to completion in FY 1980, to supplement any additional activities undertaken in support of program developments, and to coordinate Phase I and Phase II activities. Because of the reactive nature of this task, no detailed work plan will be presented.

Major milestones and deliverables for Phase II are presented in Table 4.2-1 and Fig. 4.2-1. Management and resources allocations for Phase II are presented in Table 4.2-2. 
Table 4.2-1. Milestones - FY 1979 - Phase II

\begin{tabular}{cc}
\hline Date & Deliverable \\
\hline June 1,1979 & $\begin{array}{c}\text { New commity and impact assess- } \\
\text { ment/monitoring contracts in } \\
\text { place }\end{array}$ \\
June 15,1979 & $\begin{array}{c}\text { Contributions to Socond Progrcoo } \\
\text { Report from all tasks }\end{array}$ \\
September 15,1979 & $\begin{array}{c}\text { Contributions to Annual Report } \\
\text { from all tasks }\end{array}$ \\
\hline
\end{tabular}


Decentralized Solar Energy TA Program - Milestones FY 79 - Phase II

Task/Activity Dct. Nov. Dec. Jan. Feb. Mar. Apr. May June July Aug. Sept.

Community TA Comparisons

Assessment/Monitoring

Progress/Annual Reports

General Support
Dct. Nov. Dec. Jan. Feb. Mar. Apr. May June July Aug. Sept.
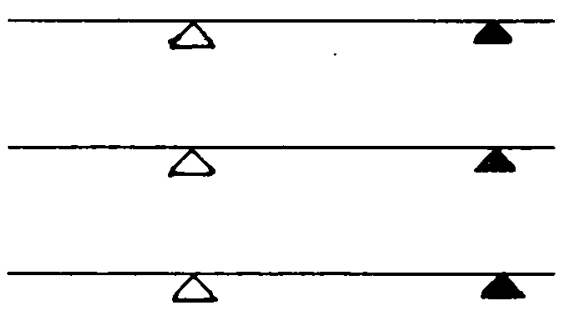

as needed

$\Delta=\operatorname{draft} \quad \Delta=$ final

Fig. 4.2-1. Milestone Chart - FY 79 - Phase II 


\section{MANAGEMENT}

Program Manager: Benson H. Bronfman

Task Leaders:

1.1-i M. Sichweitzer

S. A. Carnes

II-2 B. H. Bronfman

II-3 B. H. Bronfman

RESOURCES

Budget: $\quad$ Approximately $255 \mathrm{k}$

Staff Time: 1.0 person/years

Eubcontracts: $200 \mathrm{k}$ 


\subsection{Background and Support Studies}

Initiated by DOE, the background and support studies were designed to assist communities in developing their technology assessments by providing examples, or prototypes, of decentralized solar scenarios, and by analyses and assessments of important social issues which are likely to affect the development and utilization of decentralized solar technologies.

The first major task (III-I) is the development of three prototypical scenarios for the utilization of solar technologies by different types of communities, and a community design primer directed at the energy planning process. Scenarios are being developed for urban, suburban, and rural areas by three separate groups. Scenarios should include the determination of energy requirements, a solar energy "inventory," mixes of supply technology impacts on the environment, etc. The planning handbook will focus upon the design of buildings, neighborhoods and communities to make maximum use of solar energy utilization. This first task (III-1) has been funded by grants from National Endowment for the Arts through a DOE interagency agreement. A more detailed description of the activities in this task is contained in Section 10.0 .

The second major task dealing with social issue analysis (III-2) consists of two activities. One activity is an analysis of value issues in technology assessment. This effort is directed at developing an understanding of the values of those who initiate, conduct and use the technology aeseesment, and of thooc who will be affected by the policy decisions made based upon the program. A second activity is the assessment of social consequences of the widespread use of distributed solar energy systems. This activity will be undertaken through a workshop on the Social Impacts of Energy Decentralization, bringing together representatives of DOE, researchers in various aspects of the TAP and other field projects, and representatives of different disciplinary approaches to the analysis of decentralization. A more detailed description of task III-2 is contained in Section 11,0 , 
Because ORNL does not play a direct management role in the Background and Support study effort, and because of the nature of the funding arrangements, a detailed milestone and deliverable description will not be provided. Table 4.3-1 shows the major contracting institutions, principal investigators, and approximate level of funding. All final products are expected in the fourth quarter of FY 1979. 
Table 4.3-1. Management and Resources for Background and Support Studies

\begin{tabular}{|c|c|c|c|c|}
\hline Task & Activity & Institution & $\begin{array}{c}\text { Principal Investigator } \\
\text { (current) }\end{array}$ & $\begin{array}{l}\text { Level of funding } \\
\text { (approximate) }\end{array}$ \\
\hline \multirow[t]{4}{*}{ III-1 } & Rural scenario & $\begin{array}{l}\text { Univ. of Massachusetts - } \\
\text { Amherst }\end{array}$ & David Pomerantz & $30 \mathrm{k}$ \\
\hline & Urban scenario & $\begin{array}{l}\text { Institute for Local } \\
\text { Self-Reliance }\end{array}$ & David Morris & $30 \mathrm{k}$ \\
\hline & Suburban scenario & SUNY Stony Brook & Dr. Robert Nathans & $30 \mathrm{k}$ \\
\hline & $\begin{array}{l}\text { Energy Design } \\
\text { Primer }\end{array}$ & $\begin{array}{l}\text { AIA Research } \\
\text { Corporation }\end{array}$ & Karen Hobson & $60 \mathrm{k}$ \\
\hline \multirow[t]{2}{*}{ III-2 } & $\begin{array}{l}\text { Values in Tech- } \\
\text { nology Assessment }\end{array}$ & $\begin{array}{l}\text { Institute on Man and } \\
\text { Science }\end{array}$ & Dr. Gordon Enk & $20 \mathrm{k}$ \\
\hline & $\begin{array}{l}\text { Decentralization } \\
\text { Workshop }\end{array}$ & $\begin{array}{l}\text { Institute on Man and } \\
\text { Science }\end{array}$ & Dr. Gordon Enk & $40 \mathrm{k}$ \\
\hline
\end{tabular}




\subsection{COMMUNITY LEVEL TECHNOLOGY ASSESSMENT PLAN: TASK I-1}

PURPOSE

The purpose of this task is to assess the social, economic, institutional and life-style impacts of the widespread utilization of decentralized solar technologies. By placing this task in a community context the assessment will be more responsive to community needs and goals, will involve local citizens in consideration of their energy future, and will entail the adaptation of a mix of solar technologies to specific community contexts - both physical and preferential.

\section{APPROACH}

Three small communities have geen funded to undertake their own solar TA. One community is in the Northeast - a 3-county area centered in Corning, New York. Richmond, Kentucky has been selected as the experimental community in the Southeast. A third community - Kent, Ohio - has been selected as the Midwestern site. Responsibility for the management of the Midwestern community has been delegated to ANL. All community projects will be underway in May, 1979.

Communities were selected on the basis of several criteria including: Merit of appruach

Qualifications of subcontractor

Familiarity with local problems

General TA programmatic needs

Working teams will be formed within the community to develop a plausible solar future (scenario) or futures for the local area. The scenario(s) will be based upon community energy needs, community goals and preferences, availability of solar resources, and other agreed upon values. The working team will represent local government officials, planning officials, and local citizens and interest groups, and will have access to information sources in areas such as technology, economics, etc. 
A plan for presenting the results of this exercise to the community will be developed, and may involve such mechanisms as the media, public participation events, and educational programs.

An assessment of the perceived social, economic, institutional and lifestyle impacts of the scenario(s) will be undertaken; with a wide range of citizen involvement. The precise mechanisms (workshops, small groups, etc.) are left to the communities.

The stress placed upon each major component, the specific nature of each component, and the process by which the components are integrated are left to the individual contractor. The "mix" of solar technologies selected and the total amount of profected solar penetration are also left to the individual contractor.

Coordination and communication among the three communities will be maintained through systematic interchanges between community contractors, project contract (technical) managers and project principal investigator.

The internal milestones for Task I-1 are presented in Table 5.1. 
Table 5-1. Internal Milestones - Task I-1

\begin{tabular}{ll}
\hline \multicolumn{1}{c}{ Date } & Milestone \\
\hline May 15, 1979 & All contracts in place \\
June 1, 1979 & $\begin{array}{c}\text { Comparison of three comminity } \\
\text { plans }\end{array}$ \\
June 15, 1979 & $\begin{array}{c}\text { Material for Second } \\
\text { Progrese Report }\end{array}$ \\
September 15, 1979 & Material for Annual Report \\
\hline
\end{tabular}




\subsection{SOCIAL COST PLAN: TASK I-2}

\subsection{Activity I-2-A: Social Costs Assessment}

PURPOSE

To develop a method for the assessment of the social costs of alternative energy technologies. To apply the method in the assessment of solar vs conventional energy technologies

APPROACH

The comparative assessment of the social costs of alternative energy technologies is hampered by inadequacies and imbalances in existing data about impacts and methodologies for evaluating them.

Several major concerns will be addressed in this research activity

1. Problems of specification. There is considerable debate about what constitutes a "social" cost. Specific categories will be developed and defined.

2. Problems of aggregation. Significant information may be lost when costs are aggregated to represent a technology-wide impact.

3. Problems of dimensionality. Social costs will vary according to several dimensions of development and application, among which are:

(a) technology life cycle: construction, operation, shutdown

(b) fuel cycle: extraction, transportation, fabrication, etc.

(c) temporal: long- vs short-term impacts

(d) spatial: site, region, national

(e) level of impact concern: individual, group, society

(f) equity: distribution of burdens and benefits 
4. Measurement specificity. Social costs vary on the appropriate level of precision for quantifying them (i.e., nominal, ordinal, interval or ratio leve1).

5. Analysis and integration. Methods for aggregation and integration of a wide range of cost data will be examined.

This activity will involve an extensive review of the literature, and an application of findings to specific technologies, focusing upon solar technologies. The review of the literature will help to establish categories of social costs, and to collect data on how social costs have been measured and evaluated in the past. An application of the findings to selected energy technologies will then be undertaken.

\subsection{Activity I-2-B: Legal and Institutional Barriers}

PURPOSE

To provide communities with a comprehensive review of major legal and institutional barriers to the introduction and deployment of decentralized solar technologies.

\section{AFFROACII}

This effort is a comprehensive literature review of major restrictions, regulations, incentives and deployment strategies for decentralized solar technologies.

A detailed outline of the proposed draft report is presented below:

\section{Major Legal Issues in the Use of Decentralized Solar Energy}

I. INTRODUCTION

A. The Purpose of this Research

1. Support for Solar TA Communities 
2. Provide information for other interested parties

a. energy policy-makers (state and federal)

b. local planners and administrators

c. solar industry

d. potential solar users

B. Research Methodology

1. Reviewed relevant literature

2. Defined five major solar legal issues

C. The Major Issues Identified

1. Restrictions on the Use of Solar Technologies

a. Briefly describe basic issue

b. List regulatory devices involved in restricting solar technology

1) Pub1ic statutes

2) Private agreements

2. Regulation of production, placement and service of solar equipment

a. Briefly describe basic issue - an amalgam

b. List component issues

1) Warranties and consumer protection.

2) Solar standards and codes

3) Union involvement

4) Mandatory installation

5) Anti-trust

6) Aid to sma11 businesses

7) Liability of manufacturers, retailers, and installers

8) Patents and licenses

3. Access to sunlight

a. Briefly describe basic issue

b. List different approaches to protecting solar access

1) The concept of "sun rights"

2) Assuming solar access through established land use controls

3) Other legal devices for protecting solar access

4. Financial incentives and impediments to the use of solar technologies 
a. Briefly describe basic issue

b. List potential incentives and impediments

1) Taxes

2) Lending policies and interest rates

3) Pricing of competing fuels

4) Government procurement policies

5) Insurance and owner liability

5. The Public Utility - Solar User Interface:

a. Briefly describe basic issue

b. List questions of importance

1) Utility rates

2) Utility. service policies

3) Provision of solar equipment by utilities

4) Authority of public utility commissions

D. Plan of the Report

1. Treat each major issue separately in Chapters 2-6

2. Summarize each issue and their relative importance in Chapter 7

II. RESTRICTIONS ON THE USE OF SOLAR TECHNOLOGIES

A. Brief Re-statement of the Basic Issue

B. Discuss Regulatory Devices Involved in Restricting Solar Technologies

1. Yublic statutès

a. Zoning (briefly define "zoning").

1) Set-back, lot coverage, height, use, and auxiliary structure requirements can prevent use of solar devices. Example:

2) Modification of existing zoning laws can allow solar, use. Local control with State and Federal push Example:

3) Importance

b. Aesthetic controls (briefly define)

1) Restrictions on architectural style, roofing materials, and auxiliary structures can prevent solar devices. Example:

2) Modification of laws can allow solar. Example: (State and federal governments have roles) 
3) Importance

c. Building codes (brief1y define)

1) Lack of material and testing standards can discourage builders from installing solar systems

2) Adoption of solar standards can alleviate the above (Federal, state, and model code efforts)

2. Private agreements

a. Restrictive covenants (Deed Restrictions) - briefly define

1) Aesthetic and architectural restrictions can forbid solar usage

2) New developments can avoid such restrictions but nullifying existing ones is questionable. Federal and state efforts

3) Importance

III. REGULATION OF PRODUCTION, PLACEMENT, AND SERVICE OF SOLAR EQUIPMENT

A. Brief,Restatement of the Basic Issue

B. Discuss Sub-Issues

1. Warranties and consumer protection

a. Traditionally, warranties and certification have been lacking

b. Current effort to institutionalize solar industry accountability. State activities

c. Importance

2. Solar standards and codes

a. Most locales still have no solar codes; slow building approval

b. Standards development at Federal, state and private consensus level. Example: MPS, NBS, State efforts

c. Importance

3. Union involvement

a. Example from earlier new technologies indicates possible difficulties. Could impede solar use

b. Current union interest in solar is growing. Example

c. Possible conflicts over jurisdiction and work assignments. Federal and state role

d. Importance 
4. Mandatory installation

a. Use of solar devices could be mandated. Example:

San Diego County. State and Federal role?

b. Importance

5. Anti-trust

a. Assuming competition in solar industry is a Federa1

concern. Lack of competition can slow solar development and use

b. Importance

6. Aid to small businesses

a. Closely related to. Issue 5. Small solar businesses may be hurt by entry of large corporations: Possible Federal actions

b. Importance

7. Liability of manufacturers, retailers, and installers

a. Liability considerations can discourage solar industry

b. Lack of accountability can discourage potential consumers

c. Possible state, Federal role

d. Importance

8. Patents and Licenses

a. Federal policy can affect solar innovation. Patent rights, background, patents, and Iiçenses

b. Importance

IV. ACCESS TO SUNLIGHT

A. Brief Restatement of the Basic Issue

B. Discuss Different Approaches to Protecting Solar Access

1, The conọept of "Sinn RiglıLs" - allowā solar cullectors to receive needed sunlight

a. Early examples. English Doctrine of Ancient L1ghts

b. Denial of common law sun rights in 20th Century America. Examp 1e: Tuinlalneblcau

c. Modern attempts to insure "Sun-rights" - Federal, state, and local interest

1) Water-rights analogy. Example: New Mexico state law

2) Licenses or permits for protecting solar devices.

Example: proposed Massachusetts law 
3) Shadows on collectors as Public Nuisance. Example: Proposed Colorado law

4) Absolute right to light in specific zones

d. Importance

2. Assuring solar access through established land use controls a. Zoning

1) Set back, height, and other requirements can adversely affect access to sunlight

2) Proposed zoning ordinances can protect solar access. Local actions, with state-enabling legislation and possible Federal impetus. Traditional and envelope zoning. Examples:

3) Influence on land use patterns

4) Differences between established and newly developing areas. Example

5) Importance

b. Subdivision regulations

1) Existing regulations can impede solar use

2) Sub-regulations can be used to aid active and passive solar usage. Local authority with state-enabling legislation and possible Federal role. Example

3) Resulting land use patterns

4) Importance

c. Solar access easements - Public (eminent domain) and privately negotiated

1) Can protect access to active and passive solar devices. Much state activity: enabling local recording of easements. Examples

2) Resulting land use patterns

3) Importance

d. Vegetation controls

1) Control of vegetation can be used to protect solar access

2) Importance

e. Restrictive covenants

1) Private agreements can protect solar access on neighborhood level

2) Resulting land use patterns

3) Importance 
3. Other legal devices for protecting solar access

a. Transferrable Development Rights

1) TDR can compensate owners for restricting development to protect solar access

2) Importance

b. Environmental Impact Assessments

1) Solar access can be considered in EIS for residential and commercial developments

2) Importance

V. FINANCIAL INCENTIVES AND IMPEDIMENTS TO THE USE OF SOLAR TECHNOLOGIES

A. Brief nestatcment of tho Bacic Ieeue

B. Discuss Potential Incentives and Impediments

1. Taxation

a. Property tax

1) Can discourage solar devices by taxing them as additional value

2) Tax exemptions can make solar more attractive. Much state action here. Examples

3) Importance

b. Sales and use taxes

1) Fixemptions here can make solar more competitive. State action. Examples

2) Importance

c. Income tax

1) Tax credits can encourage solar use. Federal and States active here. Examples

2) Importance

2. Lending policies and interest rates

a. Wilingness of financial institutions to Lend money for solar devices and prevaling interest rates strongly affects attractiveness of this capital-intensive technolugy. 'l'endency has been to underappralsc solar bulldings for loan purposes. Example

b. Importance

3. Pricing of competing fuels

a. Price of competing fuels greatly affects solar attractiveness. Federal role in price regulations 
b. Importance

4. Government procurement policies

a. Government purchase of solar equipment can stimulate production and lower prices. Federal, state, and local role

b. Importance

5. Insurance and owner liability

a. Insurance costs and possible owner liability affect attractiveness of solar option

b. Importance

VI. THE PUBLIC UTILITY-SOLAR USER INTERFACE

A. Brief Restatement of the Basic Issue

B. Discuss Questions of Importance

1. Utility rates - strong state role

a. Certain rate schedules can penalize solar users

1) Demand charges. Example

2) Declining block rates. Example

3) Stand-by charges

b. Other rate schedules can encourage solar usage

1) Peak/off-peak pricing

2) Life-line rates. Example

3) Flat rate

4) Inverted rate

5) Interruptible service rates. Example

c. Importance

2. Utility service policies

a. Utility decisions on providing back-up power can greatly affect feasibility of solar use. Strong state role

b. Importance

3. Provision of solar equipment by utilities

a. Utilities selling or leasing solar equipment may further solar use

b. Utilities selling or leasing solar equipment may hurt sma11 companies and consumers and act to discourage solar use. State role in regulating this involvement

c. Importance 
4. Authority of public utility commissions

a. State will have to decide if joint solar systems should be regulated as utilities

.b. Questions exist as to authority to regulate "end-use" of power: Example

c. Importance

VII. SUMMARY AND CONCLUSIONS

A. Description of the Current Legal Climate for Decentralized Solar Energy Use

B. Discussion of Relative Importance of 5 Major Issues in Affecting Solạr Use

C. A Brlef Look at the Future of these Solar Legal Issues

A summary of internal milestones for both activities in the Social Cost task is presented in Table 6-1. 
Table 6-1. Internal Milestones - Task I-2

\begin{tabular}{lc}
\hline Date & Milestone \\
\hline June 15, 1979 & $\begin{array}{c}\text { Draft Reports - both activities } \\
\text { Material for Second Progress } \\
\text { Report }\end{array}$ \\
August 31, 1979 & Final Reports - both activities \\
September 15, 1979 & Material for Annual Report \\
\hline
\end{tabular}




\subsection{GENERAL SUPPORT PLAN: TASK I-3}

\subsection{Activity I-3-A: Program Review Team}

PURPOSE

To review TA program progress, identify strengths and weaknesses, suggest new directions or redirections, and serve in an advisory capacity to principal investigators and DOE program manager.

\section{APPROACH}

A program review team wili he tormed, compocod of professionals experiéncèd in solar energy, technology assessment and community decision-making. The review team will have periodic meetings, and results of these meetings will be communicated to all members, including the Program Manager. A document covering the activities of the review team and an overall review of the TA program will constitute the final report. This activity is subcontracted to The Institute on Man and Science.

\section{Review Team Membership}

$\begin{array}{ll}\text { Dr. A. Christakis } & \text { Battelle Memorial Institute } \\ \text { Mr. Douglas Bolcyn } & \text { Fortlaid General Electrlc } \\ \text { Dr. Gordon Enk } & \text { Institute on Man and Science } \\ \text { Dr. Paul Friesema } & \text { Northwestern University } \\ \text { Dr. Roy Rappaport } & \text { University of Michigan } \\ \text { Mr. Ronald Stewart } & \text { SUNY Albany } \\ \text { Dr. Benson H. Bronfman } & \text { ORNL } \\ \text { Dr. Eugene Franke1 } & \text { DOE/PE } \\ \text { Mr. Robert Odland } & \text { SERI } \\ \text { Mr. James Quinn } & \text { DOE/ETS }\end{array}$




\subsection{Activity I-3-B: Selected Case Studies}

PURPOSE

To gather information about significant community-based activity related to deployment of solar technologies.

\section{APPROACH}

Several communities in the United States have taken direct action to encourage or mandate the deployment of solar technologies and to guarantee access to solar resources. Where these actions appear, upon initial review, to be of potential significant interest to DOE and the TA program, brief case studies will be undertaken.

Major questions to be addressed will include:

1. Who were the mafor interest groups or principal actors responsible for the introduction of the action?

2. What were the major issues or legal questions?

3. What was the nature of the action?

4. What type of public involvement characterized the adoption of local plans?

5. What characteristics of the communities made them receptive to the use or deployment of solar technologies?

6. How much energy was to be replaced by solar energy, and, has the action been successful?

\subsection{Activity I-3-C: Review and Liaison}

PURPOSE

To provide timely review and information exchange between components of the TA program, DOE, and project staff. 
APPROACH

Since this activity will be undertaken in support of the overa11 TA program and evolving programmatic needs, no detailed plan can be developed. Sub-activities will include:

1. Familiarization with other relevant community and regional studies.

2. Liaison with the decentralized studies program at SERI and other DOE decentralized and regional solar programs.

3. Monitoring of past activities of the TA program including

(a) scenario development tasks

(b) decentralization workshop (IMS)

(c) values in TA study (IMS)

4. Review of DOE proposals and plans for DOE

A summary of major internal milestones for this task is presented in Table 7-1. 
Table 7-1. Internal Milestones - Task I-3

\begin{tabular}{cc}
\hline Date & Milestone \\
\hline June 15, 1979 & $\begin{array}{c}\text { Material for Second Progress } \\
\text { Report }\end{array}$ \\
September 15, 1979 & Material for Annual Report \\
\hline
\end{tabular}




\subsection{EXPANDED COMMUNITY TECHNOLOGY ASSESSMENT PLAN: TASK II-1}

\section{PURPOSE}

To increase TA program flexibility and to examine a diversity of community settings and approaches for greater generalizability of findings.

APPROACH

Two additional communities will be added to the first three community TAs. One community will be Franklin :County, Massachusetts, which has already completed a scenario development task and some communication of results to the community at large. This project had been previously funded through NEA, by a DOE interagency agreement. Results of this effort indicate that additional, limlted tunding for an assessment w111 produce a cumpleted TA, at the level of the first three TAs.

A second community will be selected either from a pool of supertor proposals received from the first round of TAs, or from responses to a new RFP intended to insure equitable regional or geographic distribution of community TAs.

Internal milestones for this task are presented in Table 8-1. 
Table 8-1. Internal Milestones - Task II-1

\begin{tabular}{lc}
\hline Date & Milestone \\
\hline June 1, 1979 & $\begin{array}{c}\text { New community contracts in } \\
\text { place. Commity TAs begin }\end{array}$ \\
June 15, 1979 & $\begin{array}{c}\text { Material for Second Progress } \\
\text { Report } \\
\text { September 15, } 1979\end{array}$ \\
\hline
\end{tabular}




\subsection{COMMUNITY IMPACT ASSESSMENT/MONITORING PLAN: TASK II-2}

PURPOSE

To provide Project principal investigator with appropriate and timely information on each of the community TAs for the purposes of program evaluation and intercommunity comparison

\section{APPROACH}

An independent (from TA task team) observer, or observers, will be contracted in each community, through a local university, to monitor community impacts of the TA process, including but not limited to

(1) a chronology of program and related events;

(2) major controversies arising within TA project, and over the project in the community;

(3) access to the process by interested parties within and outside the community;

(4) spillover effects to other community planning efforts and activities;

(5) major actors, principal interests;

(6) roles played by community vs. consultants; and

(7) unanticipated problems or impacts.

To undertake an adequate evaluation of the TA program and the TA task team effort in several communities, and for a more comprehensive management effort, an ongoing data gathering/monitoring effort within the communities is required. Because the community TA task team members will be intimately involved in the assessment process, it is unlikely that they will have the time, resources or objectivity required to recognize and monitor significant actions or events affecting the community. Further, it is unlikely that a monitoring or evaluation effort will have credibility (especially if the findings are positive) unless the effort is contracted separately from the community TA effort. 
It is also proposed that the monitoring effort be undertaken in an essentially passive mode of recording and observation. It is felt that active involvement by another party in the community may cast doubt as to the "real" purpose of the project for the community and has the potential for impacting negatively on the TA process through the introduction of exogenous concerns.

Given the above concerns, the project can best be served by instituting an independently contracted monitoring effort, responsible to the principal investigator, and feeding into an evaluation of the TA process in the selected communities.

We will require monthly reports, which will be synopsized and communicated to DOE program management, as part of ORNL's management responsibilities. Internal milestones for this task are presented in Table 9-1. 
Table 9-1. Internal Milestones - Task II-2

\begin{tabular}{cc}
\hline Date & Milestone \\
\hline June 1,1979 & $\begin{array}{c}\text { Monitoring contractors selected } \\
\text { and plans approved }\end{array}$ \\
June 15, 1979 & $\begin{array}{c}\text { Material for Second Progress } \\
\text { Report }\end{array}$ \\
September 15, 1979 & Material for Annual Report \\
\hline
\end{tabular}




\subsection{SCENARIO DEVELOPMENT PLAN: TASK III-1}

PURPOSE

The purpose of the scenario development task is to prepare a set of prototypical scenarios for solar utilization at the community level: Scenarios will be developed for three different types of communities urban, suburban and rural/small town. The scenarios can be used by the community TA task teams as examples of methods and approaches to scenario construction for technology assessment. Additionally, a planning and design energy primer will be prepared as an aid to communities for organizing, presenting and working on solar/community planning and design concerns.

\section{APPROACH}

Three scenarios will be developed by three groups with experience in energy development at the community level.

The scenario for an urban area is being undertaken by the Institute for Self Reliance, and the study area is Baltimore, Maryland. The objective of the study is to show how solar energy can be used, together with conservation, to replace 50 percent of fossil fuel requirements by the year 2000 . A significant contribution has been the conceptualization of the city as a potential single energy consuming and producing system, whereby some buildIngs are net producers of solar electric power (e.g., warehouses) while others are consumers (e.g., multiple family units). This concept, together with appropriate storage for thermal energy, seem to indicate that the goal of 50 percent reduction in fossil fuel consumption is feasible. A second important contribution will be a description of the opportunities, obstacles and imperatives that communities will find as they move to the solar future.

The suburban scenario is being directed from SUNY at Stony Brook. The scenario development begins with a review of the Nassau/Suffolk regional land use plan. Study communities will be selected to examine the use of solar energy in the context of the regional land use plan. Bay Shore, Long Island, 
is studied as a redevelopment site, a new development will be selected in the neighborhood of Patchogue and Coram, Long Island, and an industrial park development will also be studied. The assessment of the impacts of solar utilization upon community development assumes that $100 \%$ of energy needs will be provided through the use of solar energy. Impact assessment and recommended actions will be organized into those specifically associated with land use development and planning design criteria. A solar master plan will be developed to maximize the widespread use of solar technologies.

The rural/small town scenario is managed by the Future Studies Program at the University of Massachusetts, Amherst. The focus for the study is Franklin County, Massachusetts, and the major assumption is that all energy for Franklin County comes from renewable resources, primarily solar. For this area of Massachusetts, the study will: 1) develop historical energy use data, 2) develop various energy scenarios for a time frame after $2000 \mathrm{AD}$, 3) develop a solar energy inventory for the target area for the same period, 4) reconcile the energy source inventory to the various energy demand scenarios by end use congruence, 5) examine primary effects of such need satisfaction, and 6) examine secondary and tertiary effects of such need satisfaction. Throughout this exercise a consulting board of reviewers will be used extensively. Highly technical aspects will be subcontracted to a variety of subject matter specialists, who will be local residents if possible. Finally, a comprehensive scenario suitable for public interactions and evaluations will be produced.

The Community Energy Design Primer is being developed by the American Institute of Architects. Research Corporation. The Primer tries to increase the awareness and understanding of both the community member and the local planning official in terms of the available methods for reducing the community's dependence on depletable sources of energy. It also looks at the potential impact of those energy reduction strategies on the form and shape of the community. The Primer examines the basic principles of energy conservation in the built environment, along with alternative technologies and design strategies that can be used to reduce community energy consumption. 
The Primer will have four major components:

- Energy use in the built environment, including a catalogue of energy saving ideas

- A guide for planners for the inclusion of energy related considerations in the planning and design process

- A guide for community members interested in undertaking the planning process for themselves

- A bibliography of existing publications and case studies on energy use in the built environment and available energy reduction strategies 


\subsection{SOCIAL ISSUE ANALYSIS PLAN: TASK III-2}

PURPOSE

This task is directed at understanding certain elements of the social setting in which the TAP and solar energy development are taking place. The objectives are to provide assistance to individuals participating in and utilizing the results of the TAP, and to begin to address the potential societal implications of the widespread use of decentralized solar technology.

\section{APPROACH}

Two efforts have been undertaken by the Institute on Man and Science. The first effort is an analysis of value issues in technology assessment. A major conclusion of the effort is that the values of all involved in the TAP must be clarified - in its management, its community participation efforts, and its technical analyses - before anything can be said about the relationship between values and solar technologies.

A second effort will be a workshop on the social impacts of energy decentralization. The intent is to specify what is usefully known about the relationship between societal decentralization and energy production, distribution and use, in the context of various technological options. Participants in the workshop will include those from DOE working in policy capacities with decentralized solar technologies, researchers involved in various efforts in the TAP, representatives of different disciplinary approaches to the analysis of decentralization, and representatives of field projects concerned with decentralized energy. 
ORNL/TM-6913

\section{INTERNAL DISTRIBUTION}

$\begin{aligned} \text { 1. } & \text { H. G. Arnold } \\ 2 . & \text { S. I. Auerbach } \\ 3 . & \text { L. G. Berry } \\ \text { 4. } & \text { F. D. Boercker } \\ 5 . & \text { R. B. Braid } \\ \text { 6-10. } & \text { B. H. Bronfman } \\ \text { 11. } & \text { L. M. Bronfman } \\ \text { 12. } & \text { R. S. Carlsmith } \\ \text { 13-17. } & \text { S. A. Carnes } \\ \text { 18. } & \text { C. V. Chester } \\ \text { 19. } & \text { R. M. Davis } \\ 20 . & \text { W. Fulkerson } \\ 21 . & \text { R. B. Honea } \\ 22 . & \text { S. V. Kaye } \\ 23 . & \text { E. G. Llewellyn } \\ 24 . & \text { A. S. Loeb1 } \\ 25 . & \text { J. W. Michel } \\ 26 . & \text { W. R. Mixon } \\ 27 . & \text { J. C. Moyers }\end{aligned}$

\author{
28. D. C. Parzyck \\ 29-33. E. Peelle \\ 34. H. Postma \\ 35. C. R. Richmond \\ 36. M. W. Rosentha1 \\ 37. T. H. Row \\ 38-42. G. Samuels \\ 43-47. M. Schweitzer \\ 48. T. Takayama \\ 49-53. T. J. Wilbanks \\ 54-55. Central Research Library \\ 56. Y-12 Technical Library \\ 57-61. Laboratory Records \\ 62. Laboratory Records (RC) \\ 63. ORNL Patent office
64-114. Social Impact Analysis Group of the Regional and Urban Studies Section, Energy Div.

\section{EXTERNAL DISTRIBUTION}

115. Office of Assistant Manager, Research and Development, DOE-ORO

116-142. Technical Information Center, DOE-ORO

143. Douglas R. Boleyn, Portland General Electric, 121 S.W. Salmon St., Portland, OR 97204

144. Alexander Christakis, Battelle Memorial Institute, Washington Operattons, $2030 \mathrm{M}$ Street, NW, Washingtó, DC 20037

145. Gordon A. Enk, Director of Economic and Environmental Studies, The Institute on Man and Science, Rensselaerville, NY 12147

146. Eugene Franke1, Solar Domestic Policy Review, Department of Energy, Forrestal B1dg., GB 156, 1000 Independence Ave., NW Washington, DC 20585

147. Pau1 Friesema, Center for Urban Affairs, Northwestern University, 2040 Sheridan Ave., Evanston, IL 60201

148. Robert Odland, Solar Energy Research Institute, 1536 Cole Blvd., Golden, CO 80401

149. Roy Rappaport, Department of Anthropology, University of Michigan, Ann Arbor, MI 48104

150. Ronald Stewart, Atmospheric Science Research Center, State University of New York at Albany, Albany, NY 12222

151-200. James Quinn, Program Manager, Division of Planning and Technology Transfer, Department of Energy, $600 \mathrm{E}$ Street, NW, Washington, DC 20545 